\title{
STRATEGI PENGEMBANGAN PASAR TRADISIONAL DALAM MENINGKATKAN KEPUASAN PEDAGANG
}

\author{
Oleh: \\ Rohmat Wahyudi \\ Sekolah Tinggi Ilmu Ekonomi IPWI Jakarta \\ Email: wahyudiroh@yahoo.com
}

\begin{abstract}
ABSTRAK
Pasar tradisional merupakan bentuk ekonomi kerakyatan dan juga merupakan salah satu pilar ekonomi nasional di Indonesia. Kondisi pasar tradisional sebagian besar kotor dan tidak nyaman untuk berbelanja akan tetapi tetap saja ramai di kunjungi oleh pembeli.

Penelitian ini menggunakan metode analisis deskriptif dengan pendekatan kualitatif. Lokasi penelitian adalah pasar Arriyad, Mampang Prapatan Jakarta selatan. Sampel penelitian 60 pedagang dari 289 pedagang.

Hasil penelitian menunjukan bahwa pengembangan pasar tradisional yang dilakukan Pengelola pasar Arriyadh melalui revitalisasi pasar tradisional yang bertujuan meningkatkan daya saing pasar dan mengaktifkan kembali kegiatan pasar tradisional agar dapat bersaing dengan pasar modern. Analisis strategi pengembangan pasar dalam meningkatkan kepuasan pedagang di pasar Arriyadh mencakup empat aspek diantaranya aspek sosial, aspek non fisik, aspek ekonomi dan aspek fisik. Dari analisis keempat aspek tersebut para pedagang merasa belum puas, karena sistem penindak lanjutan keluhan dan saran yang lambat, sarana dan prasarana yang belum optimal dan kesejahteraan pedagang dalam hal pendapatan tidak maksimal (menurun).
\end{abstract}

Kata kunci:

Strategi, Pengembangan Pasar Tradisional, dan Kepuasan Pedagang

\section{STRATEGI PENGEMBANGAN PASAR TRADISIONAL DALAM MENINGKATKAN KEPUASAN PEDAGANG}

\begin{abstract}
Traditional markets are a form of popular economy and are also one of the pillars of the national economy in Indonesia. The traditional market conditions are mostly dirty and uncomfortable to shop but still crowded by buyers.

This study uses descriptive analysis method with a qualitative approach. The research location is Arriyad market, Mampang Prapatan, South Jakarta. The research sample was 60 traders from 289 traders.
\end{abstract}


The results show that traditional market development is carried out by the market manager Arriyadh through traditional market revitalization aimed at increasing market competitiveness and reactivating traditional market activities in order to compete with the modern market. Analysis of market development strategies in increasing the satisfaction of traders in the Arriyadh market includes four aspects including social aspects, non-physical aspects, economic aspects and physical aspects. From the analysis of the four aspects the traders were not satisfied, because the system of follow-up complaints and suggestions were slow, facilities and infrastructure were not optimal and the welfare of traders in terms of income was not optimal (decreased).

\section{Keywords:}

Strategy, Traditional Market Development, and Trader Satisfaction

\section{PENDAHULUAN}

Cita-cita dalam bernegara adalah untuk mewujudkan masyarakat yang adil dan makmur. Untuk mewujudkan cita-cita itu maka perlu melaksanakan pembangunan. Melalui pembangunan, pemerintah bermaksud meningkatkan kemakmuran masyarakat secara bertahap dan berkesinambungan, yaitu dengan cara meningkatkan konsumsinya. Karena peningkatan konsumsi sangat tergantung pada peningkatan pendapatan, dan peningkatan pendapatan sangat tergantung pada peningkatan produksi, maka sebagai pelaku ekonomi setiap anggota masyarakat selayaknya turut serta dalam proses pembangunan. Secara teoretis, bila semua ikut menghasilkan, maka semuanya akan ikut menikmati.

National Training Laboratories Institute menyatakan, "dengan memanfaatkan pengetahuan dan teknik yang berasal dari ilmu-ilmu perilaku, pengembangan organisasi berupaya untuk mengintegrasikan kebutuhan individual untuk tumbuh dan berkembang bersama dengan tujuan dan sasaran organisasi agar dapat membuat organisasi lebih efektif. Dari pernyataan tersebut dapat ditarik kesimpulan bahwa organisasi bisa dikatakan sebagai pasar yang sedang ingin berkembang dengan bantuan pemerintah yaitu melalui kebijakan revitalisasi pasar, tetapi tidak hanya sekedar kemajuan yang nampak dari segi fisik yang nyaman saja. Akan tetapi harus memperhatikan tujuan dan sasaran yang akan dicapai dengan konsistensinya pada segi respon petugas pasar, monitoring serta evaluasi program. Dengan demikian dapat tercapai tujuannya dengan efektif dan memuaskan.

Pasar tradisional merupakan bentuk ekonomi kerakyatan dan juga merupakan salah satu pilar ekonomi nasional di Indonesia. Berdasarkan data dari Ikatan Pedagang Pasar Indonesia (IKAPPI) jumlah pasar tradisional turun drastis dari 9.950 menjadi 9.550 pasar dalam waktu 6 tahun (2011-2017). Total jumlah pedagang pasar tradisional berkisar 10.625 .000 orang. Pada 2015 terdapat 144 pasar terkena konflik akibat revitalisasi dan 161 pasar hangus karena kebakaran. Dari data tersebut belum termasuk jumlah untuk pemasok, tukang ojek, petugas parkir, keamanan yang tentunya juga banyak beraktivitas di pasar tradisional. Sungguh merupakan jumlah yang cukup besar sehingga tidaklah berlebihan ketika ada pernyataan bahwa pasar tradisional merupakan salah satu pilar perekonomian di Indonesia. 
Meskipun saat ini pasar tradisional mulai mendapat tekanan dari pertumbuhan pasar modern, akan tetapi tidak dapat kita pungkiri bahwa keberadaan pasar tradisional telah ada sejak puluhan atau ratusan tahun yang lalu. Sebagian besar pasar tradisional yang ada di Indonesia merupakan saksi sejarah dan memiliki nilai cagar budaya. Pertumbuhan pasar modern yang semakin pesat akan berpengaruh terhadap kelangsungan hidup pasar tradisional. Meskipun selama ini pasar tradisional telah dapat bertahan selama bertahuntahun, akan tetapi jika tidak ada perubahan kearah yang lebih baik maka pasar tradisional hanya akan menjadi sebuah sejarah dan akan berdampak kepada pedagang pasar tradisional yang akan kehilangan mata pencahariannya. Peran pasar tradisional sebagai pilar perekonomian nasional juga tidak akan mampu mendukung pertumbuhan perekonomian di Indonesia

Kondisi pasar tradisional sebagian besar kotor dan tidak nyaman untuk berbelanja akan tetapi tetap saja ramai di kunjungi oleh pembeli, hal ini merupakan sebuah peluang yang berhasil di manfaatkan oleh para investor untuk membuat suatu konsep tempat belanja baru yang lebih baik dan nyaman. Seharusnya baik itu karena ada pasar modern yang lebih bersih dan rapi ataupun tidak, penataan dan perawatan pasar tradisional seharusnya tetap dilakukan. Bukannya seperti sekarang ini yang muncul istilah baru yaitu revitalisasi pasar. Sebenarnya hal itu hanyalah menunjukkan ketidak pedulian pemerintah selama ini.

Sumber daya manusia adalah salah satu faktor yang sangat penting bahkan tidak dapat dilepaskan dari sebuah organisasi, baik institusi maupun perusahaan. Pada hakikatnya, SDM berupa manusia yang dipekerjakan di sebuah organisasi sebagai penggerak, pemikir dan perencana untuk mencapai tujuan organisasi itu. Konsep pemberdayaan untuk optimalisasi nonfisik yang harus dilakukan, menurut pandangan Ketua pengelola pasar Arriyadh dilakukan dengan beberapa tahapan

1) Pemberdayaan aparat atau pegawai pasar, dengan melakukan rapat bulanan. Ini harus melibatkan jajaran direksi dan karyawan, maupun perwakilan paguyuban pedagang sebagai bentuk penyaluran aspirasi.

2) Sosialisasi ke pedagang untuk mematuhi disiplin atas peraturan yang dibuat bersama. Ini termasuk pemeliharaan kebersihan dan ketertiban di pasar dalam membayar retribusi tepat waktu dan meningkatkan kompetensi pedagang

3) Pemberdayaan pedagang dadakan dan pedagang lapak dengan cara menempatkan mereka masuk ke dalam lingkungan pasar dan menjadi pedagang tetap.Mereka harus ditempatkan sesuai penempatan yang sudah berjalan atau hasil kesepakatan selama ini.

Revitalisasi pasar memakan biaya yang tinggi. Selain itu di beberapa tempat pengembangan pasar sering dianggap memarginalisasi pedagang lama karena pedagang ditarik retribusi yang lebih besar. Akibatnya bukan peningkatan kesejahteraan yang didapat, bahkan beberapa pedagang lama tersingkir karena tidak sanggup membayar retribusi. Dengan demikian kebijakan ini harusnya mendapat perhatian lebih supaya dapat membuahkan hasil yang maksimal.

Berdasarkan Peraturan Daerah Nomor 115 tahun 2010 tentang petunjuk pelaksanaan peraturan daerah Jakarta Selatan Nomor 4 tahun 2010 tentang pengelolaan pasar yang berisi tentang pelaksanaan bagi pengaturan, pembinaan, 
pengendalian dan pengawasan terhadap kegiatan pasar milik pemerintah daerah serta untuk lebih meningkatkan pelayanan kepada pedagang yang memanfaatkan fasilitas pasar sebagai tempat menjalankan usahanya. Tujuan ditetapkannya peraturan daerah ini adalah untuk mewujudkan pelayanan bagi masyarakat berupa penyediaan fasilitas pasar yang dapat menunjang terselenggaranya proses jual beli yang aman dan nyaman.

Salah satunya adalah pelaksanaan revitalisasi Pasar Arriyadh yang membawa dampak pada kepuasan bagi para pedagang yang berjualan di Pasar Arriyadh. Lewat penataan kembali pasar tradisional yang memperhatikan aspek kenyamanan, pelayanan dan keamanan, maka potensi yang dimiliki pasar tradisional akan dapat meningkat. Oleh karena itu, beberapa pedagang di pasar Arriyadh merasakan adanya perubahan setelah pengembangan pasar terkait revitalisasi yang telah dilakukan di pasar Arriyadh, dimana sebelumnya hampir semua pedagang memiliki SPP (Surat Penempatan Pedagang). Namun, sekarang banyak pedagang liar yang tidak memiliki SPP. Bapak Madun salah satu pedagang di pasar Arriyadh mengungkapkan bahwa beliau mengalami penurunan pendapatan karena para pembeli lebih tertarik untuk berbelanja ke pedagang liar letaknya lebih strategis dan mudah dijangkau.

Meskipun banyak pedagang yang mengeluhkan bangunan yang terasa panas karena pasca revitalisasi tidak diberi alat pendingin seperti kipas angin dan sirkulasi udara yang kurang bagus. Selain ibu Suci, dan bapak Uda pun mengungkapkan hal demikian. Pada waktu yang berbeda pedagang yang bernama ibu Ipah (40), bapak Kusno (27), dan bapak Suryo (27) mengungkapkan hal yang sama pula, bahwa mereka merasakan pelayanan yang lamban terhadap keluhan yang disampaikan dari masing-masing pedagang kepada petugas pasar setelah dilaksanakannya revitalisasi atas timbulnya pedagang liar.

\section{TUJUAN PENELITIAN}

Untuk mengetahui dan mengaanalisa strategi pengembangan pasar tradisional di pasar Arriyadh untuk meningkatkan kepuasan pedagang.

\section{TELAAH LITERATUR DAN PENGEMBANGAN HIPOTESIS}

Sumber daya manusia adalah aset yang dimiliki organisasi untuk melakukan segala aktivitas operasional organisasi. Dalam tugasnya, SDM diarahkan oleh sebuah manajemen yakni Manajemen Sumber Daya Manusia. Manajemen sumber daya manusia dapat diartikan sebagai pendayagunaan sumber daya manusia di dalam organisasi, yang dilakukan melalui fungsi-fungsi perencanaan sumber daya manusia, rekrutmen dan seleksi, pengembangan sumber daya manusia, perencanaan dan pengembangan karir, pemberian kompensasi dan kesejahteraan, keselamatan dan kesehatan kerja, dan hubungan industrial (Marwansyah, 2010: 3).

\section{Strategi Pengembangan Pasar Tradisional \\ Menurut Kamus Besar Bahasa} Indonesia (KBBI), strategi adalah ilmu dan seni menggunakan semua sumber daya untuk melaksanakan kebijaksanaankebijaksanaan tertentu dalam perang maupun damai. Secara eksplisit, strategi adalah rencana tindakan yang menjabarkan alokasi sumber daya dan aktivitas lain untuk menanggapi lingkungan dan membantu organisasi mencapai sasaran. Sedangkan Armstrong 
merumuskan strategi adalah mengenai penetapan tujuan (tujuan strategi) dan mengalokasikan/ menyesuaikan sumber daya dengan peluang (strategi berbasis sumber daya) sehingga dapat mencapai kesesuaian yang efektif dan penerapan strategi tergantung pada kapabilitas strategi organisasi yang akan memasukkan kemampuan, tidak hanya untuk memformulasikan tujuan strategi tapi juga untuk mengembangkan dan menerapkan rencana strategi melalui proses manajemen strategi.

Strategi pengembangan pasar adalah serangkaian tujuan dan sasaran, kebijakan dan aturan yang memberi arah kepada para pedagang dari waktu ke waktu, pada masing-masing tingkatan dan acuan serta alokasinya, terutama sebagai tanggapan pasar dalam menghadapi lingkungan dan keadaan persaingan yang selalu berubah. Oleh karena itu penentuan strategi pengembangan pasar harus didasarkan atas analisis lingkungan dan internal pasar melalui analisa keunggulan dan kelemahan pasar, serta analisis kesempatan dan ancaman yang dihadapi pasar dari lingkungannya Pada saat ini kegiatan pemasaran mempunyai peranan yang sangat penting dalam dunia usaha. Kadang-kadang istilah pemasaran ini diartikan sama dengan berbagai istilah, seperti penjualan, perdagangan, dan distribusi. Salah pengertian ini timbul karena pihak-pihak yang bersangkutan mempunyai kegiatan dan kepentingan yang berbeda-beda.

\section{Revitalisasi Sebagai Bentuk Pengembangan Pasar Tradisional}

Revitalisasi adalah suatu proses yang harus dilalui oleh pasar tradisional dalam persaingan era globalisasi. Banyaknya pasar modern dengan fasilitas yang memadai akan mengurangi peran pasar tradisional. Menurut Danisworo dalam (yuliani,2016) revitalisasi adalah upaya untuk memvitalkan kembali suatu kawasan atau bagian kota yang dulunya pernah vital/ hidup, akan tetapi kemudian mengalami degradasi. Revitalisasi sendiri bukan sesuatu yang hanya berorientasi pada penyelesaian keindahan fisik saja, Revitalisasi dapat dilaksanakan apabila semua pihak yang terkait saling mendukung, baik pihak pemerintah, pedagang hingga pembeli. Aspek fisik, aspek ekonomi serta aspek sosial menjadi perhatian yang utama dalam melaksanakan revitalisasi.

Dalam menjalankan aktivitas ekonomi di pasar tradisional, kondisi fisik memegang peranan yang penting. Rancangan fisik pasar harus mempertimbangkan fungsi pasar sebagai tempat aktivitas ekonomi sosial komunitas penggunanya. Program revitalisasi pasar tradisional juga menyentuh tata kelola (kelembagaan) pasar. Mewujudkan pasar yang profesional haruslah dikelola dengan manajemen yang terpadu dimana seluruh manajemen pasar terintegrasi menjadi satu. Lewat penataan kembali pasar tradisional yang memperhatikan aspek kenyamanan, pelayanan dan keamanan, maka potensi yang dimiliki pasar tradisional akan dapat meningkat.

Daya saing yang meningkat diharapkan mampu memberi keunggulan komparatif bagi pasar tradisional. Program revitalisasi pasar bertujuan untuk meningkatkan daya saing pasar dan mengaktifkan kembali kegiatan pasar tradisional agar dapat bersaing dengan pasar modern sehingga bukan hanya meningkatkan pendapatan pedagang tapi juga meningkatkan daya saing untuk memperluas pangsa pasar.

Dengan diadakannya program revitalisasi, pasar tradisional siap menyaingi serbuan pasar modern. Pasar tradisional akan kembali dilirik oleh 
konsumen jika citra buruk yang melekat selama ini dihapuskan. Kuncinya adalah pasar tradisional harus ditata sedemikian rupa sehingga keadaannya menjadi bersih dan nyaman bagi pengunjung termasuk menjaga kualitas kesehatan produk yang dijual. Pemerintah haruslah proaktif untuk menghidupkan kembali pasar tradisional begitu juga dengan para pedagang dan pengelola pasar harus konsisten untuk menjaga aura pasar tradisional untuk kebersihan pasar pasca revitalisasi tetap terjaga disertai juga dengan tata kelola pasar yang professional.

\section{Kepuasan Pedagang}

Mulanya konsep kepuasan dekat dengan kegiatan pemasaran karena adanya orientasi pemasaran terhadap kebutuhan pelanggan. Sekarang, konsep kepuasan telah merasuk ke seluruh jajaran organisasi karena keyakinan bahwa tanpa dapat membangun kepuasan pelanggan niscaya satu organisasi dapat bertahan dan berkembang. Sehingga diyakini bahwa seluruh bagian dalam organisasi mempunyai misi memberikan kepuasan baik kepada pelanggan internal maupun eksternal.

Kepuasan tidak saja sebagai tujuan organisasi, akan tetapi juga menjadi strategi (instrumen) perusahaan. Sebagai strategi, kepuasan berkaitan dengan penyusunan konsep, metode, dan evaluasi untuk dapat memenangkan persaingan. Dalam teori equity, seseorang akan puas bila rasio hasil (outcome) yang diperolehnya dibandingkan dengan input yang digunakan dirasakan fair atau adil. Dengan kata lain kepuasan terjadi bila konsumen merasakan bahwa rasio hasil terhadap inputnya proporsional terhadap rasio yang sama (outcome dibanding input) yang diperoleh orang lain (Oliver). Dalam hal ini pedagang disebut sebagai konsumen yang menerima dan merasakan sebuah produk kebijakan dari pemerintah yang memungkinkan kita memberikan nilai pada berbagai hal.

Pedagang adalah orang yang berdagang. Jadi kepuasan pedagang adalah tingkat perasaan seorang pedagang setelah membandingkan kinerja (atau hasil) yang pedagang rasakan dengan harapan yang diinginkannya. Dalam konteks ini pedagang berperan sebagai consumer dari produk-produk pemerintah yang diturunkan melalui kebijakankebijakan terhadap pengembangan pasar yang berupa revitalisasi pasar tradisional.

\section{Kerangka Penelitian}

Gambar 1

Kerangka Penelitian

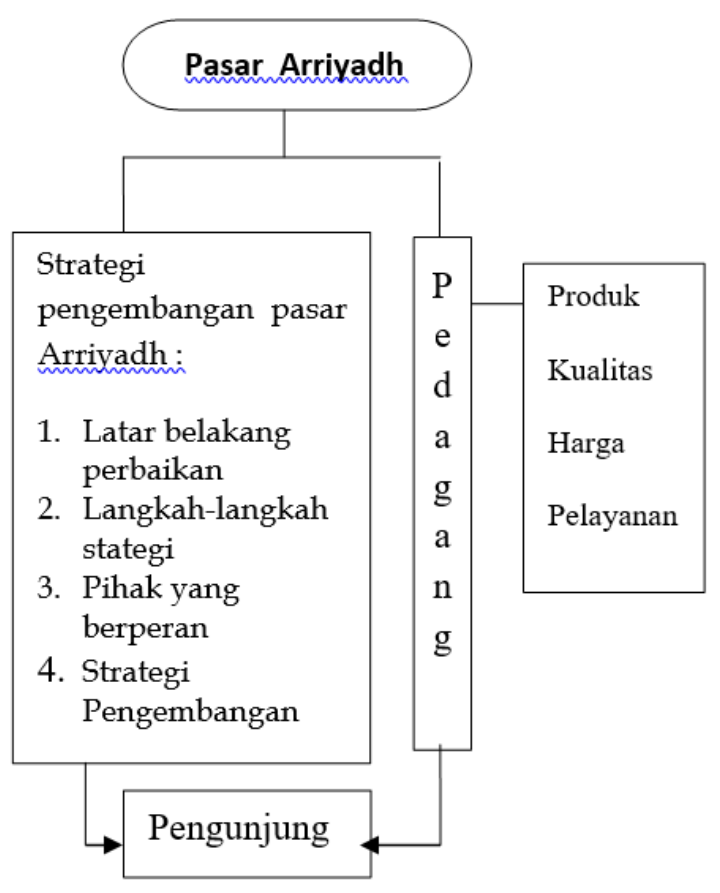

Ucang Sukriswanto (2012), Analisis Kelayakan Revitalisasi Pasar Umum Gubug Kabupaten Grobogan, menghasilkan kesimpulan Pembangunan pasar Gubug kabupaten Grobogan dari aspek ekonomi dan sosial adalah dapat diterima. Hal didasarkan pada adanya peningkatan-peningkatan yang signifikan 
terhadap perbaikan dan peningkatan taraf hidup serta perbaikan pada aspek sosial dan budaya. Sedangkan dalam penelitian ini Penelitian sama-sama didasarkan pada pembangunan pasar yang berupa peningkatan-peningakatan taraf hidup serta perbaikan pada aspek sosial dan budaya. Perbedaanya dalam penelitian sekarang pada fokus kajiannya pada manajemen pengembangan pasarnya dalam mengahsilkan kepuasan pedagang.

\section{METODE PENELITIAN \\ Tempat Penelitian}

Penelitian di lakukan di pasar Arriyadh Mampang Jakarta Selatan, sedangkan waktu penelitian di laksanakan bulan September - Desember 2018.

\section{Sampel Penelitian}

Populasi dalam penelitian ini adalah 289 pedagang pasar Arriyadh. Sampel didasarkan pada uraian Arikunto (2013), jika subyeknya besar (lebih dari 100) dapat diambil antara $10-15 \%$ atau $20-25 \%$ atau lebih." sampel 20\% yaitu 60 pedagang. Dalam penelitian ini, teknik sampling yang digunakan adalah purposive sampling, yaitu teknik pengambilan sampel sumber data dengan pertimbangan tertentu sehingga akan memudahkan peneliti menjelajahi obyek/ situasi sosial yang diteliti.

\section{Metode Analisis}

Dalam hal ini peneliti melakukan beberapa teknis analisis data, yaitu:

1. Analisis Sebelum di Lapangan

Tahap ini merupakan tahap awal yang dilakukan peneliti dengan pertimbangan etika penelitian lapangan melalui tahap pembuatan rancangan usulan penelitian Pengumpulan Data Penyajian Data Reduksi Data Penarikan Kesimpulan hingga menyiapkan perlengkapan penelitian. Analisis dilakukan terhadap data hasil studi pendahuluan, atau data sekunder yang akan digunakan dalam penulisan. Dalam hal ini data sekunder yang digunakan dalam penulisan ini adalah dengan melakukan observasi, wawancara, dokumentasi dan triangulasi.

2. Analisis Data di Lapangan

Analisis data di lapangan peneliti menggunakan model Miles dan Huberman dalam Sugiyono (2010:252). Yang mana Miles dan Huberman mengungkapkan bahwa analisis data kualitatif dilakukan secara interaktif dan berlangsung secara terus-menerus sehingga datanya sudah jenuh. Peneliti berusaha mempersiapkan diri untuk menggali dan mengumpulkan data-data untuk dibuat suatu analisis data mengenai pedagang pasar Arriyadh yang meliputi tiga proses yaitu:

a. Reduksi Data, yaitu merangkum, memilih hal-hal yang pokok, memfokuskan pada hal-hal yang penting, dicari tema dan polanya dan membuang yang tidak perlu.

b. Penyajian Data, Penyajian data ini dapat dilakukan dengan bentuk tabel, grafik, dan sejenisnya. Dan dalam penulisan ini peneliti lebih memfokuskan penyajian data dengan menggunakan teks yang bersifat naratif.

c. Verifikasi, kesimpulan awal yang dikemukakan pada tahap awal masih bersifat sementara, dan akan berubah bila tidak ditemukan bukti-bukti yang kuat yang mendukung pada tahap pengumpulan data berikutnya. 
HASIL PENELITIAN DAN

PEMBAHASAN

Hasil Penelitian

Pasar Arriyadh secara geografis terletak di sebelah selatan kota Jakarta, tepatnya di Kecamatan Mampang Prapatan, Kelurahan Mampang Prapatan dengan alamat Pasar: Jl. Tegal parang utara 5. Letak Pasar Arriyadh terletak pada posisi yang di jalan kecil Akses yang mudah dijangkau menjadikan pasar Arriyadh menjadi sasaran pembeli yang akan berbelanja di pasar tersebut. Posisi yang dekat dengan perumahan warga ini menjadikan pasar Arriyadh tidak pernah sepi dari pengunjung, terutama warga sekitaran Tegal Parang, Pancoran dan sekitarnya.

Pasar Arriyad adalah pasar yang termasuk dikategorikan pasar tua karena pasar tersebut berdiri kurang lebih pada tahun 1987, dan pada saat itu pasar Ariyadh masih dikelola oleh RT/RW setempat hingga dialihkan ke Kelurahan dan Kecamatan pada tahun 1995. Pasar tersebut sempat direvitalisasi dua tahap, yaitu pada tahun 2005 dan 2016. Pelaksanaan revitalisasi dilaksanakan bertahap dikarenakan pada tahap yaitu pada tahun 2005 dan 2016. Pelaksanaan revitalisasi dilaksanakan bertahap dikarenakan pada tahap pertama pelaksanaan revitalisasi masih dalam proses sederhana dengan hanya memberikan batasan lapak berjualan sehingga pengunjung atau pun warga yang ingin melewati jalan tersebut tidak terganggu. Pada tahap kedua revitalisasi yang di lakukan adalah pembangunan pasar baru Arriyad dengan membangun kios-kios baru yang di tujukan untuk para pedagang. Sejalan dengan berdirinya pasar Arriyadh, suatu keinginan yang tercermin dalam suatu program harus dituangkan dalam bentuk visi dan misi organisasi.
Memiliki visi terwujudnya pasar pasar tradisional yang bersih, sehat, aman, nyaman, sejahtera, dan bebas dari rentenir. Sedangkan misinya meliputi:

1) Meningkatkan dukungan dan kualitas kelembagaan serta memantapkan pelaksanaan koordinasi atas penyelenggaraan Pemerintah Daerah dalam bidang pengelolaan pasar melalui upaya optimalisasi penghimpunan dana dari pungutan retribusi pasar guna mendukung peningkatan Pendapatan Asli Daerah (PAD).

2) Meningkatkan pelayanan serta mengoptimalkan kegiatan pemberdayaan pedagang pasar dengan kebijakan pemberian bantuan dana bergulir di pasar, sehingga terwujud konsep pasar yang bebas dari jerat rentenir sekaligus kesejahteraan masyarakat pedagang pasar meningkat.

3) Mengupayakan terwujudnya basis data pasar yang simple, akurat, realis dan terpercaya dengan mengoptimalkan pelayanan secara prima kepada semua pengguna pasar serta penyediaan sarana dan prasarana pasar menuju pasar yang bersih, sehat dan nyaman.

Dengan hal tersebut, maka semua lapisan yang terkait dengan organisasi harus ikut dan mendukung kebijakan yang mengacu pada visi dan misi organisasi, sehingga tumbuh komitmen bersama untuk mengembangkan organisasi.

Pedagang yang berjualan di pasar Arriyadh rata-rata berpendidikan terakhir SD dan SMA. Pedagang berjualan paling lama selama 31 tahun. Dari hasil wawancara yang dilakukan penulis memperoleh karakteristik pedagang sebagai berikut:

Ibu Opeh, ibu Ipah, bapak Madun, Mbah, ibu Ina, bapak Tris, ibu Mutingah, 
ibu Suryati, ibu Sumarni, ibu Widari, ibu Yayah. Mereka adalah pedagang yang berjualan berupa sayur mayur di pasar Arriyadh, mereka sudah berjualan lebih dari 15 tahun, dengan berjualan hasilnya digunakan untuk memenuhi kebutuhan sehari-hari keluarga, seperti makan seharihari, membayar pendidikan anak serta memberi uang saku. Mereka berpendapat program revitalisasi pasar kurang memuaskan meskipun sudah dilakukan pembuatan gedung, penambahan sarana dan prasarana serta keamanan lebih terjamin, selain itu pendapatan pun menurun dan keluhan yang disampaikan kepada petugas pasar kurang ditanggapi serta memakan waktu yang lama untuk menindaklanjuti keluhan yang disampaikan. Dengan keluhan yang sama seperti pedagang-pedagang yang lain yaitu sempitnya lapak yang membuat pedagang tidak bisa menggelar semua barang dagangannya,serta banyaknya pedagang yang tidak memiliki Surat Penempatan Pedagang (SPP) selain itu mahalnya harga sewa kios baru sehingga para pedagang memilih untuk tetap berjualan di luar kios.

Bapak Ali, bapak Alek, bapak sakirin, bapak imron, dan bapak fiqih. Mereka merupakan pedagang sembako yang berjualan di pasar Arriyadh, yang telah berjualan lebih dari 15 tahun. Berdasarkan wawancara yang telah dilaksanakan dalam penuturan mereka, kurangnya fasilitas pendingin ruangan karena bangunan yang minim fentilasi udara.

Ibu Suci, ibu Dafira, ibu Lia, bapak Uda, ibu Rohanah, ibu Inayah, bapak Sodirin, ibu Ririn dan bapak Sono. Mereka adalah pedagang pakaian yang sudah berjualan lebih dari 5 tahun di pasar Arriyadh. Berdasarkan wawancara yang telah dilaksanakan dalam penuturan mereka, tidak adanya jaminan yang jelas dari program pengembangan pasar
Arriyadh karena berdampak pada pendapatan pedagang yang menurun setelah dilaksanakannya revitalisasi pasar. Hal ini terjadi karena suatu permasalahan yang timbul dari program revitalisasi tersebut tidak diantisipasi sebelum dilaksanakan program tersebut.

\section{Pembahasan}

\section{Pengembangan Pasar Tradisional dalam Meningkatkan Kepuasan Pedagang di Pasar Arriyadh}

Salah satu strategi pengembangan pasar tradisional di pasar Arriyadh adalah melalui revitalisasi pasar. Menurut Danisworo, (2000) revitalisasi adalah upaya untuk memvitalkan kembali suatu kawasan atau bagian kota yang dulunya pernah vital/ hidup, akan tetapi kemudian mengalami degradasi. Tujuan revitalisasi pasar adalah meningkatkan daya saing pasar dan mengaktifkan kembali kegiatan pasar tradisional agar dapat bersaing dengan pasar modern sehingga bukan hanya meningkatkan pendapatan pedagang tapi juga meningkatkan daya saing untuk memperluas pangsa pasar. Banyaknya pedagang yang menempati pasar Arriyadh, dengan segala barang dagangannya yang bermacam dan berbeda, maka pedagang tersebut dapat digolongkan sebagai berikut:

a) Pedagang ruko, adalah pedagang yang enempati bangunan yang terdiri dari toko/gudang yang bersifat permanen. Biasanya pedagang yang berada di ruko/toko ini menjual berbagai macam peralatan rumah tangga, seperti meubel.

b) Pedagang kios, adalah pedagang yang menempati bangunan yang didirikan oleh pemda dengan ukuran yang tidak begitu luas dan tidak dibangun tingkat. Contoh kios yang ada di pasar ini adalah kios pakaian dan pecah belah. 
c) Pedagang Los, adalah pedagang yang menempati bangunan yang didirikan oleh pemda dengan ukuran yang tidak begitu luas dan memiliki ciri bangunan yang pintunya dibuat sendiri dari kayu. Contoh pedagang los di pasar ini adalah pedagang pisang, pedagang bumbu dapur, pedagang sayuran.

d) Pedagang Lemprakan, adalah pedagang yang berada di emperanemperan dalam pasar Arriyadh. Pedagang ini tidak memiliki tempat atau bangunan untuk berdagang. Pedagang lemprakan biasanya hanya menggelar tikar atau terpal untuk menata dagangannya, biasanya yang berdagang dengan cara lemprakan ini menjual seperti pedagang lainnya. antara lain cabai, bumbu-bumbu dapur, dan sayuran.

e) Pedagang Kaki Lima (PKL), adalah pedagang yang berada diluar pasar untuk berjualan, dengan membawa gerobak yang berisi barang dagangannya. Pedagang dipasar ini biasanya berjualan bubur, gorengan, lontong sayur.

Segi pendidikan, pedagang di pasar Arriyadh dengan rata-rata pendidikan SMA/ sederajat yaitu 56,7\% dan sisanya SD 20\%, SMP 23,3\%,SARJANA 5\%. Sehingga daya fikir atau tingkat pemahaman tentang revitalisasi pasar dapat di pahami dengan baik.

Sementara sumber daya manusia yaitu pedagang di pasar Arriyadh di lihat dari statusnya yang menikah memiliki persentase $90 \%$ dan yang belum menikah $10 \%$, sehingga pola pikir untuk mendapatkan penghasilan demi memenuhi kebutuhan sehari-hari,biaya pendidikan anak dll semakin tinggi.

Maka dari itu apabila peran dari pengembangan sumber daya manusia ditingkatkan maka kualitas sumber daya manusia dan kinerja yang ada akan ikut meningkat. Sumber daya yang dimiliki pedagang merupakan hal penting yang harus ditingkatkan demi mencapai tujuan dalam meningkatkan pendapatan serta kualitas barang dagangan mereka yang dapat bersaing dengan kompetitif. Pengembangan sumber daya manusia dalam arti peningkatan kualitas manusia, pada dasarnya harus merupakan suatu rangkaian proses berlanjut, dari pendidikan latihan dan pengembangan (education, training dandevelopment ) yang disesuaikan dengan tuntutan kemajuan ilmu dan teknologi maupun tuntutan pembangunan

Banyak alasan mengapa banyak sekali para pedagang yang berjualan dipasar ini adalah untuk menopang kebutuhan pokok sehari hari, karena kebutuhan hidup semakin hari semakin meroket. biaya pendidikan pun semakin tinggi. Mayoritas keadaan perekonomian pedagang yang berjualan di pasar Arriyad ini adalah ekonomi menengah kebawah, karena sesuai dari hasil wawamcara dengan para pedagang penghasilan mereka berkisaran 300 sampai 500 ribu rupiah.

Berdasar penelitian ini strategi pengembangan pasar Arriyadh dalam meningkatkan kepuasan pedagang sesuai dengan penelitian Dr. Agus $S$. Ekomadyo,ST.M.T dan Ir. Sutan Hidayatusyah M.S.P (2012) tentang Pengembangan revitalisasi pasar tradisional dan hasil penelitian dari Ahmad Izanudin UIN Sunan Kalijaga Yogyakarta,2011 Kebijakan pemerintah tentang pasar tradisional di Bantul.

Jadi, strategi pengembangan pasar tradisional melalui revitalisasi pasar Arriyadh belum mencapai kepuasan jika di lihat dari segi ekonomi belum mengalami peningkatan. 
Analisis Strategi Pengembangan Pasar Arriyadh dalam Meningkatkan Kepuasan Pedagang

Kebijakan pengembangan pasar tradisional disusun dalam rangka meningkatkan pertumbuhan ekonomi di masing-masing wilayah sehingga terjadi pemerataan perekonomian di seluruh wilayah kelurahan Mampang Prapatan. Kebijakan ini disusun dengan tujuan untuk meningkatkan pertumbuhan dan perkembangan pasar tradisional sehingga aspek ekonomi adalah salah satu penunjang pertumbuhan dan perkembangan pasar tradisional, kemudian aspek non fisik dalam hal pengelolaan pasar penting, dan untuk mengakomodir kepentingan seluruh pihak yang terkait maka aspek sosial juga penting. Terakhir, aspek fisik terkait dengan kondisi fisik pasar yang dapat mendukung pertumbuhan dan perkembangan pasar.

Pemerintah Kelurahan Mampang Prapatan dalam rencana pembangunan jangka menengah daerah salah satu tujuan yang ingin dicapai adalah membangun perekonomian masyarakat menengah dengan merevitalisasi pasar Arriyadh melalui sentral pertumbuhan ekonomi pasar tradisional khususnya ditujukan kepada para pedagang yang menempati pasar Arriyadh.

Dalam hal ini manajemen sangatlah penting untuk menunjang tujuan dari sebuah rencana yang dibuat. Dengan kata lain, manajemen strategi pengembangan pasar Arriyadh haruslah dikonsepkan secara matang, supaya hasil dari rencana tersebut dapat maksimal. Namun, jika manajemen tersebut gagal maka akan mengakibatkan ketidak senangan serta ketidak puasan yang terjadi hingga menurunkan produktivitas Jika penataan hati merupakan tonggak kebaikan seluruh perilaku manusia, maka manajemen akan sangat memberikan kekuatan bagi terbentuknya organisasi yang memiliki tenaga dan maju, oleh sebab itu, maka organisasi yang baik akan tercermin dalam manajerial yang baik.

Berdasarkan data yang berhasil dikumpulkan pada program pengembangan pasar Arriyadh dapat dianalisis strategi pengembangan pasar tradisional dalam teorinya Parasuraman dalam bukunya Fathul Aminudin Aziz memiliki kesamaan variabel dengan apa yang dilakukan oleh pemerintah daerah khususnya dinas pasar Arriyadh. Empat variabel kepuasan dari strategi pengembangan pasar tersebut antara lain sebagai berikut:

1. Daya Tanggap (Aspek Sosial)

Dengan adanya revitalisasi pasar Arriyadh menimbulkan adanya perubahan sosial diantaranya adalah adanya perubahan gaya hidup, budaya, adat istiadat dan struktur sosial lainnya. Salah satu perubahan struktur sosial yang ada di pasar Arriyadh adalah adanya pasar pagi dimana pada saat sebelum revitalisasi tidak ada pasar pagi yang posisinya berada di luar pasar. Para pedagang di pasar pagi kebanyakan tidak memiliki Surat Penempatan Pedagang (SPP), namun mereka tetap diijinkan berjualan di pasar Arriyadh.

Hal ini tentunya menimbulkan rasa ketidakadilan bagi para pedagang yang memiliki SPP yang berada di dalam pasar. Karena pembeli tentunya lebih memilih untuk berbelanja di pasar pagi yang berada di luar pasar. Kadang para pelaku ekonomi hanya mementingkan keuntungan semata tanpa melihat sisi lain yang juga penting dari suatu perekonomian. Bisa saja setiap orang mencari keuntungan sesuka hati, tetapi tanpa rasa keadilan maka akan menimbulkan kerugian 
bagi orang lain. Sedangkan dalam teorinya Parasuraman, menjelaskan sikap tanggap pegawai dalam memberikan pelayanan yang dibutuhkan dan dapat menyelesaikan dengan cepat. Dan ini tidak sesuai dengan pengembangan pasar yang dilakukan oleh pemerintah daerah kshususnya pihak pasar Arriydh yang kurang tanggap dan cenderung lamban dalam menanggapi keluhan yang dialami para pedagang.

Selain para pedagang merasa diperlakukan tidak adil, para pedagang di pasar Arriyadh mengungkapkan bahwa keluhan mereka kepada petugas pasar tidak langsung ditindaklanjuti, hal ini juga merupakan salah satu aspek ketidakpuasan pedagang terhadap sikap petugas pasar. Jika mengacu pada tujuan revitalisasi pasar selain mencapai kesejahteraan pedagang, tetapi juga untuk menciptakan kenyamanan, pelayanan dan keamanan. Metode untuk mengukur kepuasan pedagang adalah adanya sistem keluhan dan saran, dimana setiap organisasi yang berorientasi pada pelanggan, perlu memberikan kesempatan yang luas kepada pelanggannya untuk menyampaikan saran, pendapat dan keluhan mereka. Sarana yang digunakan bisa melalui kotak saran, kartu komentar, atau saluran khusus bebas pulsa. Dengan cara seperti ini diharapkan suatu organisasi bisa segera memperbaiki sistem yang kurang baik dan segera mencari solusi yang tepat. Namun dalam pengelolaan sistem keluhan dan saran kurang memusakan, karena pihak pasar dalam menanggapi saran dan keluhan dari para pedagang cenderung lamban.
Aspek sosial indikatornya yaitu hasil kebijakan yang dicapai dapat memberikan manfaat kepada kebutuhan publik dan hasil kebijakan yang dicapai dapat memecahkan masalah. Hasil kebijakan yang dicapai belum memberikan manfaat kepada masyarakat dan justru terdapat beberapa masalah yang timbul setelah kebijakan dilaksanakan, yaitu keberadaan pedagang liar (pedagang yang tidak mempunyai SPP) di sekitar pasar yang telah mengganggu ketertiban umum.

Hal ini karena belum adanya sanksi yang tegas bagi para pelaku pelanggar kebijakan sehingga pelaksanaan dan hasil kebijakan belum dapat dipertanggungjawabkan secara hukum. Hal ini dapat ditunjukkan dari keberadaan pedagang yang tidak mempunyai SPP (Surat Penempatan Pedagang) yang telah berada didepan pasar sangat banyak Selama ini belum ada tindakan tegas dari pihak pasar untuk melarang mereka berjualan di depan pasar.

2. Keandalan (Aspek Non Fisik)

Tingkat keandalan dari sebuah kebijakan revitalisasi pasar dapat diukur dari sejauh mana proses manajemen revitalisasi tersebut dapat berlangsung secara kontinu pada pasar Arriyad. Proses manajemen disini tercermin dari kegiatan monitoring petugas pasar Arriyadh yang semakin lama pasca revitalisasi semakin jarang dilakukan. Sehingga terdapat kendala kurang maksimal dalam pencapaian tujuan dari revitalisasi pasar itu sendiri.

Sedangkan dalam realisasinya proses monitoring dan evaluasi program pengembangan pasar Arriyadh yang dilakukan oleh pihak pasar tidak berjalan secara konsisten, salah satu 
permasalah yang dituturkan oleh para pedagang pasar Arriyadh adalah pengawasan dari pihak pasar yang hanya berjalan pasca terdekat revitalisasi pasar Arriyadh dan kirakira hanya berjalan selama tiga bulan, padalah program pengembangan pasar tradisional melalui revitalisasi pasar adalah program jangka panjang, sehingga membutuhkan kekonsistensian dari dinas pasar Arriyadh itu sendiri.

Aspek keandalan (non fisik) meliputi manfaat kebijakan dapat dirasakan secara merata oleh seluruh pihak dan keikutsertaan pedagang dalam pelaksanaan dan pengawasan program. Pedagang hanya dilibatkan dalam pelaksanaan program tapi tidak dilibatkan dalam pengawasan program. Kegiatan monitoring dan evaluasi program dalam kebijakan pengembangan pasar tradisional dilaksanakan Disperindagkop yang dibantu oleh UPTD. Namun masyarakat kurang dilibatkan dalam pemantauan dan pengawasan program kebijakan pengembangan pasar tradisional. Sedangakan petugas pasar pun tidak kontinu dalam monitoring dan evaluasi pasca revitalisasi pasar Arriyadh. Sehingga hasil dari pengembangan pasar tersebut tidak maksimal karena permasalahn-permasalahan yang timbul baik keluhan maupun saran dari para pedagang diabaikan oleh para petugas pasar, sehingga penyampaiaanya terhadap aparat pemerintah lebih kepada manipulasi program yang tidak berjalan. Akibatnya tujuan dari revitalisasi pasar tersebut tidak mencapai target yang dinginkan.
3. Jaminan (Aspek Ekonomi)

Para pedagang yang diteliti mengungkapkan jika dilihat dari aspek ekonomi setelah adanya revitalisasi maka pendapatan mereka cenderung tetap bahkan justru menurun. hal ini tentunya tidak sesuai dengan tujuan dari kebijakan revitalisasi, dimana tujuan akhir dari adanya revitalisasi adalah mencapai kesejahteraan untuk seluruh masyarakat.

Berbeda dengan hasil dari pelaksanaan dari pengembangan pasar Ariyadh yang berakibat penurunan kesejahteraan yaitu dengan menurunnya pendapatan yang diakibatkan banyaknya pedagang liar, sehingga barang dagangan pun kurang laku terjual.

Indikator dari aspek ekonomi yaitu hasil kebijakan memuaskan kebutuhan publik. Sasaran yang diharapkan dalam kebijakan pengembangan pasar tradisional belum tercapai sehingga kebijakan ini belum memuaskan kebutuhan publik. Para pedagang di Pasar Arriyadh masih mengeluhkan mengenai kondisi pasar yang relatif lebih sepi dibandingkan dengan pasar-pasar lain, sehingga pendapatan yang diperoleh relatif menurun dari sebelum diadakannya revitalisasi pasar.

Jadi, strategi pengembangan pasar tradisional melalui revitalisasi pasar Arriyadh dari sisi aspek ekonomi dirasa belum mencapai kepuasan, dalam hal ini dilihat dari segi pendapatan yang cenderung tetap bahkan menurun.

4. Kemampuan Fisik (Aspek Fisik) Aspek fisik yang ada di pasar Arriyadh meliputi fasilitas umum (perbaikan bangunan, memperbaiki 
fasilitas yang ada seperti WC Umum), dan peningkatan kebersihan serta keamanan. Beberapa pedagang seperti Ibu Suci, ibu Dafira, ibu Lia berpendapat bahwa jika dilihat dari aspek fisik sudah memuaskan namun belum optimal karena masih ada fasilitas yang belum terpenuhi yaitu kurangnya pendingin ruangan (kipas angin/ventilasi) sehingga jika di dalam kios terasa sangat panas.

Dalam hal ini faktor-faktor yang terkait dengan fasilitas fisik yang ada setelah revitalisasi pasar Arriyadh diantaranya adalah penambahan kios, zonasi pedagang, kamar mandi pasar Arriyadh yang secara fisik sudah dilaksanakan oleh pihak pasar. Akan tetapi para pedagang mengeluhkan kurangnya fasilitas pendingin ruangan yang membuat para pedagang kurang nyaman didalam ruangan tersebut. Yang paling mendasari adalah kurangnya fentilasi udara yang masuk. Sehingga ketika siang terasa sangat panas dengan los yang yang sedikit menyempit ukurannya.

Kriteria yang paling penting dalam aspek fisik yaitu terciptanya kondisi pasar yang aman, nyaman dan bersih bagi konsumen, menciptakan pasar yang berdaya saing sehingga lebih kompetitif, dan mengurangi potensi konflik dengan masyarakat. Pada pengembangan pasar tradisional yang dapat mendukung pertumbuhan pasar tradisional yaitu dengan menciptakan kondisi pasar yang aman, bersih dan nyaman sehingga konsumen lebih suka berbelanja di pasar tradisional dibandingkan di tempat lain. Untuk menghadapi usaha-usaha lain seperti toko serba ada, mini market dan pasar swalayan maka pasar tradisional harus menjadi usaha yang kompetitif supaya tidak kalah dari usaha lainnya.

Berdasarkan dari lamanya berdagang hal yang dapat di gambarkan mengenai kondisi pasar Arriyad dengan adanya revitalisasi pasar:

Tabel 1

Perbandingan Kondisi Pasar

\begin{tabular}{|l|l|l|}
\hline Pedagang & $\begin{array}{l}\text { Sebelum } \\
\text { revitalisasi }\end{array}$ & $\begin{array}{l}\text { Sesudah } \\
\text { revitalisasi }\end{array}$ \\
\hline $\begin{array}{l}\text { Pedangang } \\
\text { los }\end{array}$ & $\begin{array}{l}\text { Bangunan } \\
\text { sudah lawas }\end{array}$ & $\begin{array}{l}\text { Bangunan di } \\
\text { perbarui }\end{array}$ \\
\hline $\begin{array}{l}\text { Pedagang } \\
\text { ruko }\end{array}$ & $\begin{array}{l}\text { Belum } \\
\text { banyak } \\
\text { bangunan } \\
\text { ruko }\end{array}$ & $\begin{array}{l}\text { Banyak } \\
\text { ruko-ruko } \\
\text { baru }\end{array}$ \\
\hline $\begin{array}{l}\text { Pedagang } \\
\text { kios }\end{array}$ & $\begin{array}{l}\text { Kios masih } \\
\text { sedikit }\end{array}$ & $\begin{array}{l}\text { Banyak kios } \\
\text { baru di } \\
\text { bangun }\end{array}$ \\
\hline $\begin{array}{l}\text { Pedagang } \\
\text { lermprakan }\end{array}$ & $\begin{array}{l}\text { Berdagang di } \\
\text { luar pasar }\end{array}$ & $\begin{array}{l}\text { Di berikan } \\
\text { tempat di } \\
\text { dalam pasar }\end{array}$ \\
\hline $\begin{array}{l}\text { Pedagang } \\
\text { kaki lima }\end{array}$ & $\begin{array}{l}\text { Berdagang gi } \\
\text { luar pasar }\end{array}$ & $\begin{array}{l}\text { Di berikan } \\
\text { tempat di } \\
\text { dalam pasar }\end{array}$ \\
\hline
\end{tabular}

Berdasarkan dari penelitian ini strategi pengembangan pasar Arriyadh dalam meningkatkan kepuasan pedagang tidak sesuai dengan penelitian Ucang Sukriswanto (2012), Analisis kelayakan revitalisasi pasar umum Gubug Kabupaten Grobongan dan penelitian Dyah Arum Istiningtyas, Analisis Kebijakan Dan strategi Pengembangan Pasar Tradisional Di kota bogor

Jadi, strategi pengeembangan pasar tradisional melalui revitalisasi pasar Arriyadh di lihat dari aspek fisik belum optimal karena masih ada fasilitas yang belum terpenuhi. 


\section{KESIMPULAN}

1. Pelaksanaan program pengembangan pasar tradisional yang dilakukan Pengelola pasar Arriyadh dalam rangka meningkatkan kepuasan pedagang melalui revitalisasi pasar tradisional bertujuan meningkatkan daya saing pasar dan mengaktifkan kembali kegiatan pasar tradisional agar dapat bersaing dengan pasar modern.

2. Analisis strategi pengembangan pasar dalam meningkatkan kepuasan pedagang di pasar Arriyadh mencakup empat aspek diantaranya aspek sosial, aspek non fisik, aspek ekonomi dan aspek fisik. Dari analisis keempat aspek tersebut para pedagang merasa belum puas, karena sistem penindak lanjutan keluhan dan saran yang lambat, sarana dan prasarana yang belum optimal dan kesejahteraan pedagang dalam hal pendapatan tidak maksimal (menurun).

\section{SARAN}

1. Untuk pengelola pasar, hendaknya meningkatkan kinerjanya secara menyeluruh dalam segala aspek sehingga dapat mengantisipasi segala kecurangan-kecurangan dan ketidak adilan yang terjadi di pasar Arriyadh, Inisiatif dari pengelola pasar sangat diperlukan dengan mengatur atau menata pedagang untuk menyewa los atau kios yang masih kosong didalam pasar khususnya pedagang yang berjualan dibahu jalan untuk saling menghormati, sehingga masalahmasalah yang terjadi di pasar dapat berkurang

2. Pelitian yang telah dilakukan ini dapat menjadi rujukan ke penelitian selanjutnya dengan responden dari pasar di wilayah lain. Penelitian selanjutnya dapat dilakukan secara kuantitatif dan kualitatis serta lebih diperluas dan diperdalam lagi variabelnya.

\section{DAFTAR PUSTAKA}

Alma, Buchari, (2014). Manajemen Pemasaran dan Pemasaran Jasa. Bandung:Alfabeta. Aminudin Aziz, Fathul., (2010). Manajemen Dalam Perspektif Islam. Cilacap: Pustaka ElBayan.

Arikunto, Suharsimi. (2013). Prosedur Penelitian Suatu Pendekatan Praktik., Jakarta: Rineka Cipta

Badriyah, Mila., (2015). Manajemen Sumber daya Manusia.Bandung : CV Pustaka Setia

Craig ; Grant. (2008). Manajemen Strategi. Jakarta: Alex Media Komputindo Kelompok Gramedia.

Creswell John.W. (2014). Penelitian Kualitatif \& Desain Riset. Yogyakarta: Pustaka Pelajar.

Danisworo, Mohammad dan Widjaja Martokusumo (2000), Revitalisasi Kawasan Kota Sebuah Catatan dalam Pengembangan dan Pemanfaatan Kawasan Kota. Diakses dari www.urdi.org (urban and reginal development institute).

H.A. Rusdiana, M., Moch. Irfan, S. M. (2016). Sistem Informasi Manajemen. Bandung: Pustaka Setia

Kotler; Philip; dan Gary Amstrong. (2008). Prinsip-prinsip Pemasaran. Jakarta: Erlangga.

Salidi Samsudin, (2010) Manajemen Sumber Daya Manusia,. Bandung Penerbit Pustaka Setia

Sangadji, E. M., Sopiah, (2013). Consumer Behavior: Perilaku Konsumen dan Strategi Pemasaran Jilid 2. Jakarta: Erlangga.

Sondang P. Siagian. (2016). Sistem Informasi Manajemen, Bumi Aksara. Jakarta.

Sugiyono. (2017). Metode Penelitian Kuantitatif, Kualitatif, dan R\&D, Alfabeta, Bandung 
Ucang Sukriswanto (2012). http:// eprints.undip.ac.id/38371/1/
Tesis_Analisis_Kelayakan_Revitalisasi_ Pasar_Umum_Gubu. 